\title{
STRATEGIC SUPPLY CHAIN MANAGEMENT OF BALI TEXTILE COMPANY IN INDUSTRIAL REVOLUTION 4.0
}

\author{
Juzer*, Director and Owner \\ Saify Textile, Indonesia \\ Darma Gede Sri, Professor and Director \\ Undiknas Graduate School, Indonesia \\ *E-mail: juzer saify@yahoo.com
}

\begin{abstract}
Textile Company is one of the industries with an important role of supporting the tourism and cultural market in Bali. Tougher business competition due to globalization effect and free trade era had shifted the business paradigm from Comparative Advantage to Competitive Advantage, which forces business activities/companies to choose the correct strategies. The purpose of this research is to understand every problem inside a textile company in Bali. In the era of industrial revolution 4.0, a textile company is forced to pay attention in all aspects in order to run the company strategy. All issues like goods supply certainty, price, product variety, credit sales, regulations, and digital marketing have been discussed in details to make readers understand about the difficulties and challenges inside the company. This research uses qualitative method and using SWOT analysis that thoroughly explain how the strength, weakness, opportunity, and threat in every issue occured in a textile company in Bali. The writers apply detailed interview technique to collect data from all the informants in textile industry chain links. The ultimate goal of this research is to improve textile industry in Bali based on accurate facts and data.
\end{abstract}

\section{KEY WORDS}

Textile, Bali, supply chain, management, Industrial Revolution 4.0, SWOT analysis.

The pattern of trade of both textile company distributor and wholesaler these days had undergone changes in industrial revolution 4.0. As described by Husein (2011:31), the company strategies can be classified based on the types of the company and the hierarchy of the duties. Distributor and wholesaler's trade is now easier to conduct with information technology tools such as WhatsApp and Instagram, unlike before the digital era where sellers must show the samples of the products offered to the buyers. Product shipping process gets faster as well due to the aid of technology, in which the seller and buyer can communicate directly to discuss the availability of the product that is about to be shipped. In the past, orders requested by distributor to the manufacturing company could be made through phone calls or facsimile, but those manners of requests made it difficult in explaining the details of colors and motifs of the order, therefore the distributor had to visit the manufacturing company to place the order him/herself. In the industrial revolution 4.0 , it is now easy to do so by using email or WhatsApp or Wechat.

In this industrial revolution era 4.0, the manners of retail textile trading had majorly changed as well. In the past, trades are done only by displaying the items in the store while waiting for the customer to come and shop. Now, trading is mostly done online because buyers prefer that. Although in purchasing textile, direct observation towards the product to understand its texture is needed, many buyers mostly ignore it now. Additionally, although buyers visit the retail establishments to shop, many want finished goods and ready-to-wear textile.

Bali Governor Directive No. 2231, 2018 states, "The implementation of Balinese Traditional Outfit and Language Application Day will start on Thursday, October 11, 2018 (Pelaksanaan Hari Penggunaan Busana Adat Bali and Bahasa Bali mulai dilaksanakan pada 
hari Kamis, tanggal 11 Oktober 2018). This regulation, published to enforce the use of traditional Balinese outfit in numerous places such as government offices, educational institutions, et cetera, created a big opportunity for textile industry in Bali as well as a threat to those in textile industry who are not ready to embrace the changes in the form of having the market switched over from them.

\section{LITERATURE REVIEW}

A research by Kuncoro Harto Widodo and Erdi Ferdiansyah (2010) entitled "Optimasi Kinerja Rantai Pasok Industri Textile and Produk Textile Indonesia Berdasarkan Simulasi Sistem Dinamis" (Optimization of Supply Chain System of Indonesian Textile Industry and Product Based On Dynamic Simulation System) resulted in 3 optimization scenarios, which is the short term, medium term, and long term scenarios. The first scnario, which also a short term suggestion, is an optimization attempt in form of minimizing or reducing the dependency in imported goods. The second scenario, the medium term strategy, is an optimization in maximizing or uplifting export by TPT Indonesia. The third scenario, which also a long term suggestion, is an optimization in form of minimizing the amount of national cottom fiber import.

Research by Agus Widyarto (2012) entitled "Peran Supply Chain Management Dalam Sistem Produksi and Operasi Perusahaan" (The Role of Supply Chain Management in Production and Operational System of A Company) generally shows the benefit of Supply Chain Management for a company, which are: First, Supply Chain Management physically can convert raw materials into finished goods and deliver them to the end customers. Second, Supply Chain Management works as market mediator, which makes sure that items provided by supply chain represent the needs of the customers or end costumers.

Research by Rusnandari Retno Cahyani (2014) entitled "Pendekatan Supply Chain Management Untuk Meningkatkan Daya Saing Pada Bisnis Bunga Segar" (Supply Chain Management Approach to Increase Competitiveness on Fresh Flower Business) shows the existence of supply chain management in a company makes it possible to achieve efficiency in fresh flower business in Surakarta's flower market (pasar kembang Surakarta) to increase competitiveness. The implementation of supply chain management is great and beneficial for the business, because this system has the advantage in managing the flow of goods or products in supply chain.

Research by Dinul Akhiyar (2016) entitled "Perancangan Aplikasi Supply Chain Management Pada Distribusi Ayam Potong PT. NUJ / MTS Dengan Menggunakan Metode Distributor Requirement Planning (DRP)" (The Design Application in Broiler Meat Distribution of P.T. NUJ/MTS by Using Distibutor Requirement Planning (DRP) Method) shows that, along with its development, computerized Supply Chain Management application is extremely beneficial in the future, proven by many trading procesess nowadays that use computerized SCM application system that can give information in order to provide good services to the customer, especially in distribution system.

Research by Teddy Dwiyangtri and Sarip Hidayatuloh (2012) entitled "Implementasi Sistem Supply Chain Management (SCM) pada PT. Carrefour Indonesia" (The Implementation of Supply Chain Management (SCM) System in P.T. Carrefour Indonesia) showed that in conducting its business, Carrefour implements Warehouse Management System, which is an InfoLog that enables all processes in supply chain to be integrated. The method used by Carrefour for this SCM is the implementation of just-in-time (JIT) process in Distribution Center/DC, called the Cross Dock. Its purpose is to make the process efficient so there is no need for stock in distribution center. With Cross Dock, Distribution Center role is improved.

Research by Desi Ariani, Bambang Munas Dwiyanto (2013) entitled "Analisis Pengaruh Supply Chain Management Terhadap Kinerja Perusahaan (Studi Pada Industri Kecil and Menengah Makanan Olahan Khas Padang Sumatera Barat)" (Analysis of Supply Chain Management Effect in The Performance of Company: A Study of Small and Medium Processed Padang Food, West Sumatra Industry) shows that to improve the company 
performance, implementation of supply chain management is needed. Information sharing, long term relationship, cooperation, and process integration are parts of the factors that influence the performance of supply chain management.

Research by Aldian Umbuh Tamu Ama, Eko Sediyono and Adi Setiawan (2014) entitled "Perancangan Sistem Informasi Manajement Rantai Pasok (Supply Chain Management) Untuk Distribusi Pangan Kabupaten Minahasa Tenggara" (Designing The Supply Chain Management Information System for Food Distribution in South East Minahasa) shows that the designing of supply chain management information system helps Food Security Office simplify the centralized data storage, especially to manage data of food result, farmers data, cooperatives data, and food distribution data.

Research by Syamsu Ramadhan, Ratya Anindita, and Suhartini (2014) entitled "Kinerja Manajement Rantai Pasok Agroindustri Emping Jagung (Kasus di Kelurahan Pandanwangi, Kecamatan Blimbing, Kota Malang)" (Supply Chain Management Performance in Agroindustry of Corn Chips: A Case in Pandanwangi Village, Blimbing subdistrict, Malang City) shows that the coordination among components in corn chips agroindustry supply chain are not formed well yet, especially in the flow of information between agroindustry - supplier and supplier - farmers. The correct choice of supplier will increase the supply chain performance in the future, and to choose the potential suppliers, Analytical Hierarchy Process (AHP) is applied.

Research by Dedy Panji Agustino (2015) entitled "Perancangan Supply Chain Management Pada Sistem Pengelolaan Mice (Meetings Incentives Conferences Exhibitions) Di STMIK STIKOM Bali" (Designing Supply Chain Management in MICE (Meetings Incentives Conferences Exhibitions) Management in STMIK STIKOM Bali) shows that computerized designing of supply chain management of MICE in STIKOM Bali is indeed needed for time efficiency and resources usage effectiveness.

Research conducted by Azizi and Faezipour (2016) entitled "Furniture industry management by applying SCM" indicated the application of SCM has improved management indices which included benefits, satisfaction of customers, financial risk, and flexibility in the volume of producing in the furniture factory. Regarding improving risk, if we want to buy raw materials from a provider, the possibility of providing those raw materials from the considered provider in specified time is called risk. When the provider is exclusive, providing risk is high and the possibility of facing shortage of raw material is high too. To better estimate the providing risk, we classify raw materials into four parts in which the first group is materials that have high providing risk and play important role in factories' strategy. About the providers of these raw materials, the method of dependency should be used so that in the long period, we don't face any problem.

Research by Cho et al., (2016) entitled "Importance of Supply Chain Management in Healthcare of Third World Countries" stated that major benefits of SCM are as under: 1. Streamlined workflow across diff teams and people involved (Fouad Maliki, Mustapha Anwar Brahami, Mohammed Dahane, Zaki Sari, 2016) 2. Have tight inventory management, so as to be economically viable, and readily available in need. 3 . Reduce failures and monetary loss due to Faulty equipment, expired medicines etc. 4. Optimize cost of equipment/medicine, by ordering in bulk or in parts as per consumption trend, and improve vendor management, by digitalizing all communication, tracking of consumption.

Research that discusses the problem in textile industry supply chain performance was conducted by Agus Purnomo in 2014, entitled Analisis Kinerja Rantai Pasok Menggunakan Metode Supply Chain Operation Reference (Scor) Di Industri Textile and Produk Textile Sektor Industri Hilir (Studi kasus pada perusahaan garmen PT Alas Indah Remaja Bogor) (Supply Chain Performance Analysis Using Supply Chain Operation Reference (SCOR) Method in Downstream Textile Industry and Product Sector: Case Study in P.T. Alas Indah Remaja Bogor Garment Company). Data collection method used in this research is observation and interview with purchasing, production planning, and marketing divisions. This research concludes that the improvement of company supply chain performance is prioritized in the source process, which is a process of providing goods and services to fulfil the demand. The processes include shipping schedule from the supplier, receiving, checking, 
and giving payment authorization to the goods sent from the supplier, choosing the supplier, and evaluating supplier's performance. Supply chain management is a reciprocal relation between the provider and the customer to deliver highly optimized values to the customers with relatively low cost but still generating profit to general supply chain (Christopher, 2011:4). Source process has the lowest performance. An attempt to improve the performance can be done by selecting capable suppliers in order to provide raw materials that are qualified, précised in amount, time, price, and contract. This can enable the establishment of long term partnership with the capable suppliers which makes the company more competitive compared to the competitors.

Based on the literature review in which the result of the research in which that source process has the lowest performance in PT Alas Indah Remaja Bogor, the researchers are interested in reconducting the research in different area and in industrial revolution 4.0 era.

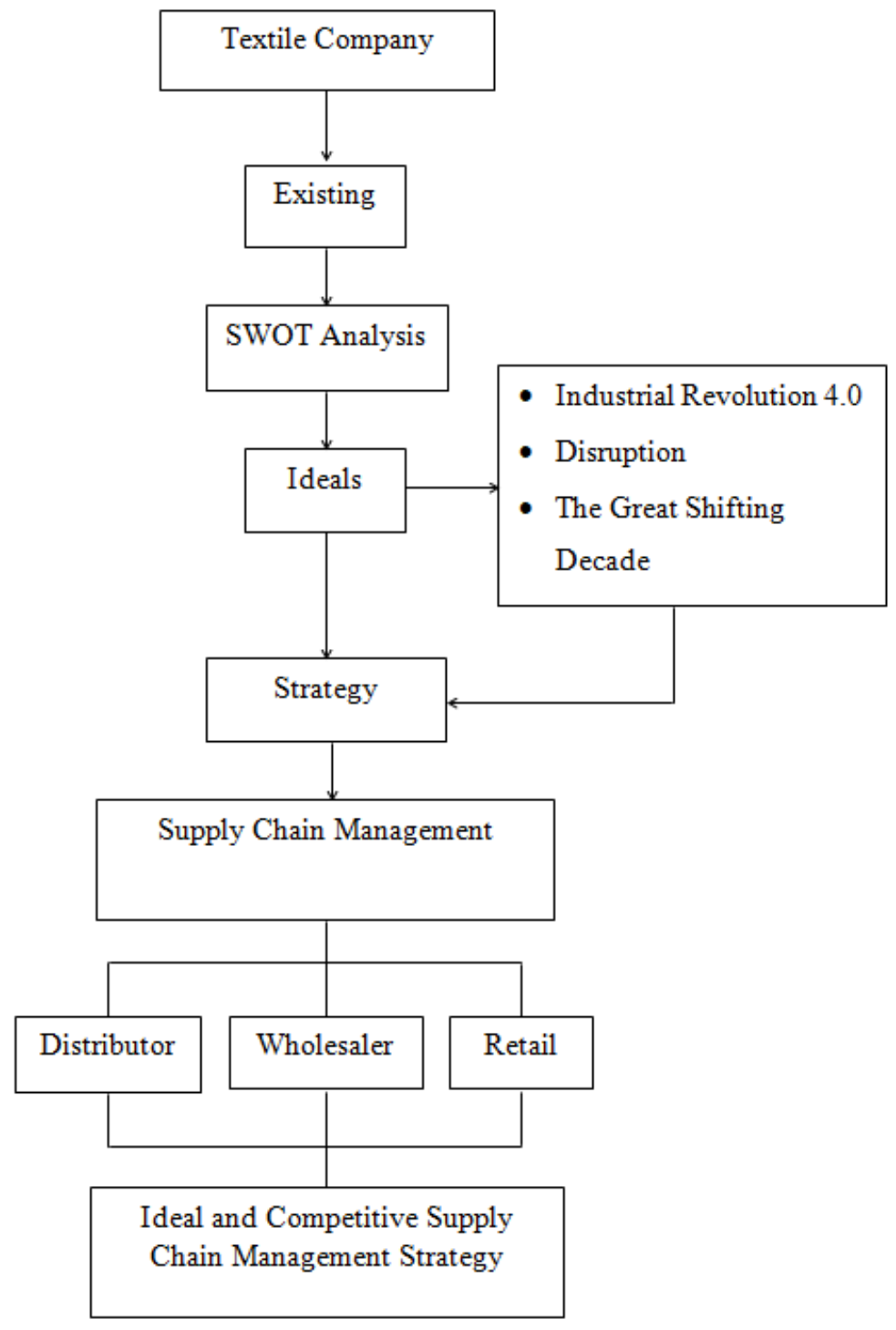

Figure 1 - Concept Chart

\section{METHODS OF RESEARCH}

This research chose Saify Textile as the source of data. Saify Textile, located in Denpasar, Bali, was chosen for the reason of being the biggest textile distributor company that can provide all information needed by the researchers in exploring the world of textile industry in Bali. 
The research implemented qualitative approach method with descriptive analysis, which is a research method based on interpretive philosophy used to research an object in its natural condition (as opposed to experiment), in which the researchers are the key instrument. Data collection technique was conducted in triangulation (combined), data analysis was done inductively or in qualitative, and the qualitative result focused more on the meaning rather than generalizing (Sugiyono, 2013).

Sampling technique used in this research is Purposive Sampling. As stated by Sugiyono (2016), Purposive Sampling is a sampling technique of data source with certain considerations. The reason for applying this Purposive Sampling technique is due to not all samples has the criteria suitable with the phenomena being researched. Therefore, researchers chose this Purposive Sampling technique which determines certain considerations or criteria that need to be fulfilled by the samples used in this research.

Researchers also collected data by interview with the informants directly related to the company. Face to face interview was conducted to 6 (six) participants to obtain solid data.

\section{DISCUSSION OF RESULTS}

Certainty of goods is one of the key successes of Saify Company in serving the customers. This is supported by Heizer and Render (2011:7), stating that supply chain design, supply, and operational decision hold an important role in determining the rise and fall of an organization. A rapid shifting of the market forced the company to always be ready in supplying goods because Saify Textile's customers have their own customers with their demand for goods' availability. The certainty of goods is very important to keep the customers not to switch to other distributors. Saify Textile competitors are always observing and ready to take the unsatisfied customers away to them. Focus on certainty of goods is very crucial and important to be done in a company. Making sure supply of goods is guaranteed will make flow of chain of commerce dynamic and sustainable.

Setting up the price for goods is a sensitive matter for both the company and the customer. A well set price will make the supply chain works well. Setting up the price determines the success of a company in selling its goods. This is due to the big demand creates free competition among the sellers. Fiercer business competition due to the effect of globalization and free trade has shifted business mindset from Comparative Advantage to Competitive Advantage that forces business activities/companies to choose the correct strategies. The strategy is where the company is in strategically position and can adapt with an ever changing environment. As stated by Ohmae (2011:10), that business strategy, in a word, is about competitive advantage. The principal going concern works here; this in general is the purpose of the establishment of a business entity. This wider information tool should at least fulfill two conditions (Hansen and Mowen, 2011): First, the information tool must include the information about the company environment and company work environment. Second, this information tool must also be prospective therefore giving a point of view about periods and activities in the future. Thus, supply chain management can be used as one of the company management analyzing tools to make strategic decisions in facing tougher business competition.

Researchers discussed about types of products. Clothing products has the biggest percentage of $70 \%$ while the rest of $30 \%$ is the cloth materials. The research itself focused on cloth materials. Saify Textile became an important factor in that needs as a raw material supplier to producers of finished clothing. Aside to fulfill the needs in tourism sector, Saify Textile also fulfills the needs for local market, which is for Balinese traditional outfit. Balinese, well known as religious in conducting their rituals, requires tools to conduct their religious routines. One of them is the traditional Balinese outfit, worn during the process of every religious ritual. People in Bali who are mostly embracing Hinduim as the religion require a huge amount of finished clothing and cloth materials supply.

Loan was also discussed by the researchers as one of the important discussions. Researchers discovered from the informant that sales in Saify Company are mostly done in loans. Researchers discussed the meaning of loan as well as the potential risks. Saify 
currently serves loan sales with two to six months maturity. Due this system, bad debt from the customers can often happen. Therefore, good evaluation in granting the loan is needed as well as a strict system in selecting new customers. An example of granting a loan will be cutting the tenor from two to six months to maximum two months in hopes to reduce the risk of bad debt. One of the reasons of this bad debt is the customer unable to read the movement of market trends when stockpiling of unsold goods happened due to trend shifting. Monitoring performance, selling, and purchasing from old customers is also still needed, this due to avoid potential problem of bad debt from old customers.

The establishment of a new regulation by the Governor of Bali in 2018 creates both positive and negative impacts. Researchers saw the need to discuss deeper about the regulation because it was deemed significant. The regulations are also followed by the directive to wear a more polite and less revealing Balinese traditional outfit. The directive which reflected deep tolerance among different religions comes with negative impact to the retail components because the use of brocade is no longer as popular as before. The seethrough nature of brocade material made it no longer usable as the main material for traditional Balinese outfit. Retailers focusing on brocade clothing should be more innovative and switch to other cloth materials as stated in the governor's directive. The positive impact was in the significant rise for diamond crape cloth sales, which is an alternative material for a more polite traditional Balinese outfit. For that matter, Saify Textile provides this type of material to fulfill its customers' needs. The availability of this materials with varieties of color and quality is also the point stated before, which is the certainty of goods.

The last but not the least important discussion is the role of digital marketing in industrial revolution era 4.0. As stated by Setyaningsih \& Vanda, 2018, Disruptive Innovation appears with new innovations that successfully replace, change, and update. Business structure, rule of playing, and structure in Disruptive Innovation means a successful transformation of a system or existing market by introducing practicality, easiness in access, comfort, and economical pricings. Marketing which holds an important role in determining the success of a company has undergone innovative changes in its function and supporting tools. The robust amount of textile manufacturers and types of raw cloth materials create varieties in the end result of a cloth. Digital marketing, in its function, is not only as a media of promotion, but also a way to attract potential customers to come and see wanted goods directly in the store. This is also beneficial and strategic for the store to make the potential customer to want or purchase other goods available in the store as well.

Solihin (2012:31) stated that strategy is defined as a process of deciding a plan by the top leaders who focus on the long term goals of an organization, along with assembling the ways for those goals to be achieved. From the result conducted in Saify Textile, we obtained the fact that Saify Textile implemented the correct supply chain management strategy to secure certainty of goods from the suppliers as well as distribution of the goods to the customers while also secured competitive price for both suppliers and customers. Saify developed strong networking with the suppliers by working together with old suppliers as well as with returning customers working together with Saify for more than 10 (ten) years. Saify provides goods in huge quantities, therefore secures a lower cost of goods to be able to compete and gain the upper hand from its competitors. Saify also gives high credit limit to its main customers so they can and are willing to purchase goods in huge amount. Saify started to change its conventional marketing pattern to digital pattern to promote and market its goods. Conventional marketing is a way to market goods by bringing the samples to each of the customers, while digital marketing is to promote goods by posting the designs or colors in social media, like Facebook and Instagram, or market the goods via WhatsApp. Saify also understands that its supply chain has not reached all regions in Bali, therefore with this digital marketing, it is expected to smoothen the distribution of its goods to the whole island. Saify also tries to reduce bad debt risks from loan sales by conducting even stricter selection in accepting new customers and maintain the returning customers from the possibility of bad debt by monitoring their performance and payments. All of the above observation is a form of SWOT analysis which had been discussed by the researchers in accordance to Freddy Rangkuti (2013), which stated that SWOT analysis is an analysis that is based on a logic that 
can maximize the strength and opportunities, but at the same time minimize the weakness and threats (analisa yang didasarkan pada logika yang dapat memaksimalkan kekuatan (strengths) and peluang (opportunities), namun secara bersamaan dapat meminimalkan kelemahan (weaknesses) and ancaman (threats). Robinson (2011) stated that SWOT analysis is one of the widely known internal and external environment analyzing tools of a company.

\section{CONCLUSION}

The purpose of the research conducted to Saify Textile Company in accordance to the application of strategic supply chain management in industrial revolution 4.0 are:

- To understand the ideal supply chain management strategy applied in textile industry in industrial revolution 4.0 compared with other strategies;

- To understand the ways for a textile company in achieving competitive advantage through ideal supply chain management in industrial revolution 4.0.

The strength and weakness in Saify Textile Company made the researchers conducted thorough discussion in all aspects by implementing SWOT analysis. The fact that even if the company had implemented supply chain management strategy, the strategies did not help the company to achieve its maximum potential; improvements and implementations of the latest technologies to boost company performance are still needed.

Researchers understand the limitations they had in not being able to research every problem in Saify Textile, thus research provided the recommendations in hopes to give guidance for the future researches related to this study, as listed below:

1. Research in different garment industry in its management and operational activities compared to the distribution companies and textile distributors. Different organization structure, marketing, and supply chain can be used for the next researchers;

2. Conducting research in retail sector due to being the end of the chain that directly links to the end users. Retail sectors consist of stores, traditional markets, and online shops can be eligible to be the next research materials.

\section{REFERENCES}

1. Agustino, D. P. (2015) 'Perancangan Supply Chain Management Pada Sistem Pengelolaan Mice (Meetings Incentives Conferences Exhibitions) Di STMIK STIKOM Bali', pp. 9-10.

2. Ama, A. U. T., Sediyono, E. and Setiawan, A. (2014) 'Perancangan Sistem Informasi Manajemen Rantai Pasok (Supply Chain Management) Untuk Distribusi Pangan Kabupaten Minahasa Tenggara', Universitas Gunadarma, 8(8), pp. 14-15. doi: 10.1017/CBO9781139087322.

3. Ariani, D. and Dwiyanto, B. M. (2013) 'Analisis Pengaruh Supply Chain Management Terhadap Kinerja Perusahaan', Diponegoro Journal of Management, 2(3), pp. 1-10.

4. Azizi, M. and Faezipour, M. (2016) 'Furniture industry management by applying SCM', Cogent Business and Management. Cogent, 3(1), pp. 1-18. doi: 10.1080/23311975.2016.1155811.

5. Berita Bali. (2018, October 11). Penggunaan Busana Adat and Bahasa Bali Diresmikan Serentak 11 Oktober. Berita Bali. https://beritabali.com

6. Arora, Monika and Grigas (2019) 'Importance of Supply Chain Management in Healthcare of Third World Countries', International Journal of Supply and Operations Management 3(1), pp. 1102-1111.

7. Christopher, Martin. 2011. Logistics and Supply Chain Management Fourth Edition. London. Prentice Hall.

8. Dinul Akhiyar (2016) 'Perancangan Aplikasi Supply Chain Management Pada Distribusi Ayam Potong Pt. Nuj Mts Dengan Menggunakan Metode Distributor Requirement Planning (Drp)', Jurnal Sains and Teknologi, 16 (2). 
9. Dwiyangtri, T. and Hidayatuloh, S. (2012). 'Implementasi Sistem Supply Chain Management (SCM) pada PT . Carrefour Indonesia', Jurnal Sistem Informasi.

10. Hansen, and Mowen. (2011). Management Biaya; Akuntansi and Pengendalian, alih bahasa Tim Salemba Empat. Salemba Empat Jakarta.

11. Heizer, Render, P., (2011). Supply Chain Management: Strategy, Planning and Operasion, 2nd or 3rd Edition. New Jersey: Pearson Prentice Hall.

12. Husein Umar. (2011). Riset Pemasaran and Perilaku Konsumen. Cetakan kedua. Jakarta: Gramedia. Pustaka Utama.

13. Ohmae, Kenichi. (2011). The Borderless World, rev ed: Power and Strategy in the Interlinked Economy. Harper Collins.

14. Purnomo, A. (2014). 'Analisis Kinerja Rantai Pasok Menggunakan Metode Supply Chain Operation Reference (SCOR) di Industri Tekstil and Produk Tekstil Sektor Industri Hilir', (2014), pp. 739-746.

15. Rangkuti, Freddy. (2013). Analisis SWOT Teknik Membedah Kasus Bisnis. Jakarta: Gramedia Pustaka Utama

16. Ratna Sari Dewantara, Setiawan, B. and Ratya Anindita. (2013). 'Analisis Rantai Pasokan Agroindustri Emping Jagung (Kasus pada Agroindustri Emping Jagung di Kelurahan Pandanwangi, Kecamatan Blimbing, Kota Malang)', 62(1), pp. 1-6. doi: 10.7498/aps/62.010302.

17. Rusnandari Retno Cahyani (2014, January) "Pendekatan Supply Chain Management Untuk Meningkatkan Daya Saing Pada Bisnis Bunga Segar", Ekonomi Bisnis \& Kewirausahaan Vol. III, No. 1

18. Robinson, Pearce. (2011). Manajemen Strategik Formulasi, Implementasi, and Pengendalian. Jakarta: Bina Rupa Aksara

19. Setyaningsih, E. D., \& Vanda, L. (2018). Analisis SWOT Financial Teknologi Pada Kualitas Layanan Perbankan di Era Disruptif.Seminar Nasional Inovasi and Tren (SNIT).

20. Solihin, Ismail. (2012). Desain Penelitian Manajemen Strategik. Jakarta: Rajawali Press

21. Sugiyono. (2013). Metode Penelitian Pendidikan Pendekatan Kuantitatif, Kualitatif, and R\&D. Bandung: Alfabeta.

22. Sugiyono. (2016). Metode Penelitian Kuantitatif Kualitatif and Kombinasi (Mixed Methods). Bandung: Alfabeta.

23. Widodo, K. and Ferdiansyah, E. (2010). 'Optimasi Kinerja Rantai Pasok Industri Tekstil and Produk Tekstil Indonesia Berdasarkan Simulasi Sistem Dinamis', Agritech: Jurnal Fakultas Teknologi Pertanian UGM.

24. Widyarto, A. et al. (2012) Peran Supply Chain Management Dalam Sistem Produksi and Operasi Perusahaan, Jurnal Manajemen and Bisnis. 